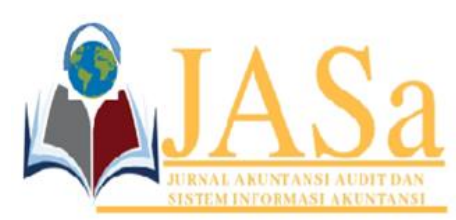

JASa (Jurnal Akuntansi, Audit dan Sistem Informasi Akuntansi)

Vol. 5 No.1/ April 2021

ISSN 2550-0732 print / ISSN 2655-8319 online

DOI; $10.36555 / j a s a / v 5 i 1.1514$

\title{
THE EFFECT OF ABNORMAL AUDIT FEE ON AUDIT QUALITY
}

\author{
Heny Dewi Ratnasari \\ Universitas Airlangga, Indonesia \\ henydeww@gmail.com
}

\begin{abstract}
This study aims to examine the effect of abnormal audit fees, which is the difference between actual audit fees and normal audit fee levels, on the audit quality proxied by accrual discretionary. The study was conducted on 414 samples of manufacturing companies listed on the Indonesia Stock Exchange for the 2013-2018 observation period. The multiple linear regression test results show a relationship between the main variables is asymmetric, which depends on the sign of abnormal audit fees. For observations with negative abnormal audit fees or below normal audit fee levels, it's showed that there is no significant effect between audit quality and abnormal audit fees. The findings indicate that there is a negative effect between abnormal audit fees and audit quality when tested on observations with positive abnormal audit fees or above normal audit fee levels. These results indicate that there is a dependence between the auditor and the client when the client pays a high audit fee so that it is possible to let the client manage earnings through discretionary accruals, which decreases the audit quality.
\end{abstract}

Keywords: Abnormal audit fee, audit quality, discretionary accrual

\section{INTRODUCTION}

The agency problem has resulted in a separation of ownership and management that runs the company, thus creating the need for external audit services. Companies that go public must submit annual financial reports that have been audited by an independent party, namely an external auditor. The objective of the audit assignment is to guarantee the credibility of the financial statements issued to the public of good quality and reliability.

The auditor will charge a fee for the audit services provided which is called an audit fee or what is called the actual audit fee. the actual audit fee consists of two parts, the first is the normal audit fee which reflects the expenses for the business issued by the auditor, litigation risk, and normal profit and the second part is the abnormal audit fee which more specifically on the relationship between the auditor and the client (Choi et al., 2010). The normal audit fee is determined by the following factors: company size, client complexity, client risk which can be observed directly through the data presented on the annual report. Meanwhile, abnormal audit fees are unobservable because of the special relationship between the auditor and the client (Jung et al., 2016).

The purpose of this study is to identify the effect of abnormal audit fees on audit quality. Investigations are conducted to determine audit fees above or under normal levels associated with audit quality. Audit quality in this study proxied by discretionary accrual. Audit quality can be said to be of good quality, which is closely related to low earnings management (Asthana \& Boone, 2012). This study also wants to assess 


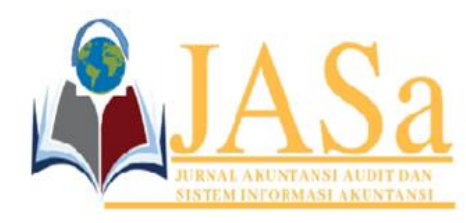

JASa (Jurnal Akuntansi, Audit dan Sistem Informasi Akuntansi)

Vol. 5 No.1/ April 2021

ISSN 2550-0732 print / ISSN 2655-8319 online

DOI; $10.36555 / j a s a / v 5 i 1.1514$

whether there are audit firms in Indonesia imposing audit fees on their clients at an abnormal level and the extent to which this will affect audit quality and financial reporting quality. The relationship between audit fees and accrual earnings management has been conducted several times. However, previous studies have shown asymmetrical results. For example, (Frankel et al., 2002) found that firms that pay higher audit fees exhibit lower levels of accrual earnings management, meaning that audit quality improves as a result of additional audit fees paid by clients. (Ashbaugh et al., 2003), gave the result that audit fees were not significantly related to the size of discretionary accruals. This study emphasizes the total audit, namely audit fee, and non-audit fee.

Subsequent research developed by dividing into components of normal audit fees and abnormal audits then testing audit quality with abnormal audit fees (Hoitash et al., 2007; Choi et al., 2010; KrauB et al., 2015; Jung et al., 2016; Alhadab, 2018). The study suggests that the abnormal level of audit fees is a major determinant that should be examined when examining the relationship between audit fees and audit quality rather than the normal level of audit fees examined by previous research.

An abnormal audit fee is defined as the audit fee received by the auditor above or below normal audit fee levels. When the audit fee is abnormally higher than the normal audit fee level it's called a positive abnormal audit fee. Whereas when the audit fee is abnormally lower than the normal level of audit fee it's called a negative abnormal audit fee (Jung et al., 2016). This study examines not only overall observations of abnormal audit fees but also divides the abnormal audit fees according to their sign, namely positive abnormal audit fees and negative abnormal audit fees (KrauB et al., 2015).

Based on the background that has been described above, the problem formulations that can be identified are as follows: (1) Does abnormal audit fee affect audit quality? (2) Does a positive abnormal audit fee affect audit quality? (3) Does a negative abnormal audit fee affect audit quality?

The fees paid to the auditors reflect the business costs and litigation risks that will be borne by the auditors (Alhadab, 2018). The difference in actual observed costs between clients will primarily reflect differences in effort cost and client-specific risk. Actual audit fee costs have limited ability to capture additional important information, so it needs to be separated into two components, namely normal audit fees, which can be observed based on factors such as company size, company risk, and complexity, and the second component is abnormal audit fees namely audit fees that are less than or more than the normal audit fees (Eshleman \& Guo, 2014). Abnormal audit fees reflect more on the contractual relationship between the auditor and his client (Mitra et al., 2009). This suggests that abnormal audit fees may provide additional information regarding the relationship between the auditor and the client.

Several previous studies used abnormal fee and actual cost metrics when examining associations with audit quality, sample analysis that combined clients with positive abnormal and negative abnormal fees (Alhadab, 2018). If the relationship between audit fees and audit quality is conditioned without any sign of abnormal audit fee, the researcher may observe an insignificant relationship for this sample as a whole because of possible cancellation effects caused by the asymmetric relationship between the two subsamples. Therefore, this study estimates that abnormal audit fees are not 


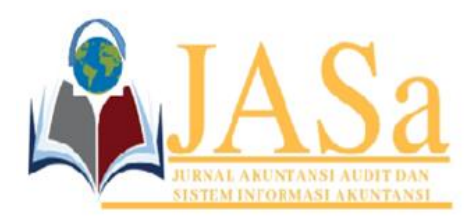

JASa (Jurnal Akuntansi, Audit dan Sistem Informasi Akuntansi)

Vol. 5 No.1/ April 2021

ISSN 2550-0732 print / ISSN 2655-8319 online

DOI; $10.36555 / j a s a / v 5 i 1.1514$

significantly related to audit quality when the relationship between the two is not conditioned on signs of abnormal audit costs.

$\mathrm{H} 1$ : Abnormal audit fees do not affect audit quality

Xie et al., (2010) stated that the objectivity and independence of auditors can be affected by audit fees received beyond their normal level, which is then called a positive abnormal audit fee. If the auditor receives an abnormally high audience fee from the client, this will result in the auditor becoming dependent on the client financially and creating an economic bonding between the auditor and the client. When a client pays abnormally positive fees, the benefits to the auditor from retaining these profitable clients may outweigh the costs associated with enabling substandard reporting (for example, increased risk of litigation, loss of reputation, etc.). The emergence of financial dependence from auditors on their clients is called economic bonding theory (Fitriany, 2016).

According to previous literature, public accounting firms that accept abnormally high audit fees will have an incentive to allow clients to engage in opportunistic earnings management (Choi et al., 2010; Jung et al., 2016; Kinney and Libby, 2002). They also note that strong economic ties between auditors and clients will reduce the quality of reported earnings because auditors tend to tolerate bias by clients in reported accounting figures through opportunistic earnings management (Kinney \& Libby, 2002). This relationship is valid as long as the profits derived from an audit engagement are greater than the costs of the possible problems that arise. High audit fees can lead to an indication of auditor independence that is compromised by allowing more manipulation of earnings (Jung et al., 2016).

Research predicts that audit quality will decrease when auditors are paid more than normal levels of audit fees themselves. Auditors will be tolerant of earnings management actions taken by management, given the fairly tight competition in the audit market in Indonesia. Client pressure and economic dependence can be the cause for the auditor to act according to the client's will. Therefore, the second hypothesis of the study follows:

H2: Positive abnormal audit fees have a negative effect on audit quality.

Apart from the positive abnormal audit fee, it is also possible that the client will pay less than the normal level of audit fees. When audit costs are abnormally low, the auditor may not be able to provide adequate audit resources to ensure audit quality. Low audit fees reflect the large bargaining power of clients (Blankley et al., 2012), which is associated with low audit quality. On the other hand, the audit costs can be low because the audit risk of the company that is assessed by the auditors is also low, therefore it requires fewer audit resources. In this condition, abnormally low audit fees will not be related to audit quality.

According to Choi et al., 2010, there are three possibilities in analyzing the relationship between negative abnormal audit fees and audit quality. First, auditors who accept abnormally negative audit fees will have little incentive to compromise audit quality by tolerating clients for substandard reporting. The reason is that the profit the auditor will get when retaining this client is not large enough to cover the costs arising 


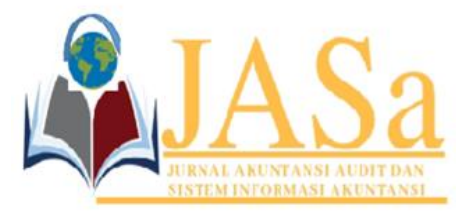

JASa (Jurnal Akuntansi, Audit dan Sistem Informasi Akuntansi)

Vol. 5 No.1/ April 2021

ISSN 2550-0732 print / ISSN 2655-8319 online

DOI; $10.36555 /$ jasa/v5i1.1514

from the compromise. Therefore, it can be predicted that there will be an insignificant or weak relationship between negative abnormal audit fees and discretionary accruals.

Second, there is a possibility that the greater the negative abnormal audit fee, the lower the incentive for the auditor to be willing to compromise his independence and the higher the audit quality (the smaller the number of discretionary accruals). In such cases, it can be observed that there is a positive relationship between abnormal audit fees and discretionary accruals for clients with negative abnormal audit fees.

Third, when the auditor incurs low audit fees in anticipation of high audit costs from future profitable engagements (negative abnormal audit fees in this period), the auditor may become vulnerable to client pressure to allow biased financial reporting. To the extent that the discount from current fees compromises auditor independence, it is expected that there is a significant negative effect between abnormal fees and discretionary accruals for clients with negative abnormal audit fees.

Research by (KrauB et al., 2015) provides findings that abnormal audit fees are negatively related to audit quality. This means that auditors can provide the right level of audit quality even when audit fees are below normal levels. Auditors have a lower incentive to compromise their independence. Besides, these results imply that low levels of audit fees are not always compensated through reduced audit effort. Therefore, the prediction of the negative relationship between abnormal audit fees and audit quality is as follows:

$\mathrm{H} 3$ : Negative Abnormal audit fee has a positive effect on audit quality.

\section{METHODS}

This research is categorized as a type of quantitative research that uses an associative approach. The dependent variable in this study is audit quality which is proxied by discretionary accruals. The independent variable used in this study is the abnormal audit fee. The control variables used in this study are:

1. Audit tenure (ADTNR), Audit tenure is the length or duration of years that a client is bound to the same audit office (Kalanjati et al., 2019)

2. Company size (LNTA), Larger firms tend to have more stable and more predictable operations and therefore often report lower levels of discretionary accruals than smaller firms (Alhadab, 2018),

3. Auditor office reputation (BIG4), what is meant here is an accounting firm that is included in the big 4. BIG4 is used as a proxy for auditor office size because previous research in auditing (Asthana \& Boone, 2012; Choi et al., 2010; Jung et al., 2016) indicated that BIG4 audit offices are expected to provide higher audit quality than non-BIG4 audit firms.

4. Changes in sales (CHGSALES), control the company's profitability and growth because companies that operate poorly are likely to have greater incentives to manage profits (Fitriany, 2016).

5. Operating cash flow (CFO), to control firm performance because the dependent variable is discretionary accruals, adjusted for performance (Kothari et al., 2005). 


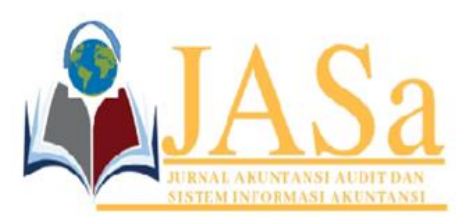

\section{JASa (Jurnal Akuntansi, Audit dan Sistem Informasi Akuntansi) \\ Vol. 5 No.1/ April 2021 \\ ISSN 2550-0732 print / ISSN 2655-8319 online \\ DOI; $10.36555 /$ jasa/v5i1.1514}

6. Leverage (LEV), (Kalanjati et al., 2019) argue that companies with high leverage are more likely to manage earnings to avoid violating debt covenants; therefore, this study also includes the LEV.

7. Book to market ratio (BTM), to control for firm profitability and growth.

8. LagTA, control for variations of the reversal effect derived from accruals over time

9. Whether the company suffered a loss (LOSS),

10. Fundraising from an external or internal source (ISSUE), and

11. FIRST which reflects the lowballing effect.

Abnormal audit fees will be tested with 3 sample categories, namely, the whole sample, positive abnormal audit fees, and negative abnormal audit fees. Testing was performed using multiple linear regression analysis and tool Stata 13.

\section{Population and Sample}

Companies that are included in the manufacturing category and listed on the Indonesian Stock Exchange (IDX) during the 2013-2018 period. The sample used in the study was obtained by carrying out a purposive sampling technique, namely the technique of obtaining a sample by determining several appropriate criteria.

Other corporate sectors are excluded, for example, finance (such as banks, insurance, and investment) because these companies have different financial reporting structures, so the measurement of company size, company risk and company complexity are determining factors in the normal audit fees equation model in this study will also give different results. The final sample data recap can be seen in table 1 .

Table 1 Recapitulation of sample data

\begin{tabular}{|c|c|c|c|c|c|c|c|}
\hline Population Criteria & 2013 & 2014 & 2015 & 2016 & 2017 & 2018 & Total \\
\hline $\begin{array}{l}\text { Manufacturing } \\
\text { companies }\end{array}$ & 136 & 143 & 146 & 154 & 154 & 163 & 885 \\
\hline $\begin{array}{l}\text { Do not have audit fees } \\
\text { data in the annual } \\
\text { report }\end{array}$ & 83 & 82 & 81 & 77 & 73 & 75 & 471 \\
\hline Totals & 53 & 61 & 62 & 69 & 81 & 88 & 414 \\
\hline
\end{tabular}

Source: data that has been processed by the author (2019)

\section{Technique and Data Analysis}

The analysis technique used is as follows:

Fisrt, looking for the abnormal value of the audit fee by using the estimation of normal audit costs using the model that has been done by Jung et al., 2016 and previous studies (Choi et al., 2010; KrauB et al., 2015; Eshleman \& Guo, 2014). The normal audit fee is calculated as the difference between the actual audit fee (stated in the annual report) and the estimated normal audit fee obtained from the model or it can be seen from the residual value. The normal audit fee estimate is obtained from performing multiple linear regression analysis on the following model: 


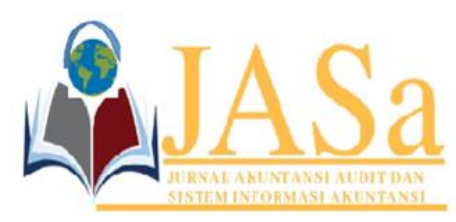

JASa (Jurnal Akuntansi, Audit dan Sistem Informasi Akuntansi)

Vol. 5 No.1/ April 2021

ISSN 2550-0732 print / ISSN 2655-8319 online

DOI; $10.36555 / j a s a / v 5 i 1.1514$
AFEE $=\beta_{0}+\beta_{1}$ LNTA $+\beta_{2}$ EMPLOY $+\beta_{3}$ INVREC $+\beta_{4}$ EXPORT $+\beta_{5}$ LIQ $+\beta_{6}$ LEV $+\beta_{7}$ $\mathrm{ROA}+\beta_{8} \mathrm{LOSS}+\beta_{9} \mathrm{GRW}+\beta_{10} \mathrm{BIG} 4+\beta_{11} \mathrm{OPINI}+\beta_{12} \mathrm{FIRST}+\beta_{13} \mathrm{ISSUE}+$ $\beta_{14} \mathrm{FOR}+$ Industry + Year $+\varepsilon_{\text {abnFee }}$

Description:

AFEE : Natural logarithm of actual audit fees in the annual report

LNTA : Natiral logarithm of total assets

EMPLOY : Square root of the number of employees

INVREC : The ratio of accounts receivable and inventory to total assets

EXPORT : Proportion of export sales to total sales

LIQ : : Current assets divided by current liabilities

LEV $\quad$ : Total debt divided by total assets

ROA : Return on Assets

LOSS $\quad: 1$ if the company reports a loss, and 0 if vice versa

GRW : Profit growth

BIG4 : 1 if the company is audited by KAP Big 4 , and 0 if the other way around

OPINI $\quad: 1$ if the company gets an unqualified opinion and 0 if the opposite

FIRST $\quad: 1$ if the auditor changed in year $t$ and 0 if vice versa

FOR : Percentage of foreign ownership

ISSUE $\quad: 1$ if the number of shares outstanding increases by $10 \%$ and 0 otherwise

EabnFee : Residual (abnormal audit fee)

Industry : Industry dummy

Year : Years dummy

Calculate the discretionary accrual value. As in many previous studies, this study uses a discretionary accrual as a proxy for audit quality. Audit quality cannot be directly observed (Asthana \& Boone, 2012). Discretionary Accrual is a model whose components are most often used by managers to opportunistically manage earnings and auditors allow these manipulations to remain without correction, so they can reflect audit quality (Hoitash et al., 2007). Discretionary accruals can be used to increase or decrease profits depending on the manager's incentives.

Jeong et al. (2014) report that managers are more likely to use discretionary accruals to perform earnings management because evidence is not easily recognized or identified in financial statements. High discretionary accruals can be considered the result of opportunistic behavior. The greater the DA value, the greater the accrual management used to increase revenue. Discretionary accruals are calculated as the residue of the following regression models, following the modified Jones Model (Jones, 1991; Kothari et al., 2005):

$$
\begin{aligned}
\frac{\text { TACit }}{\text { Ait-1 }}= & \beta_{0}+\beta_{1}\left(\frac{1}{\text { Ait-1 }}\right)+ \\
& \beta_{2} \frac{\Delta \text { REVit }-\Delta \text { RECit }}{\text { Ait }-1}+\beta_{3} \frac{\text { PPEit }}{\text { Ait-1 }} \\
& +\beta_{4} \text { ROA }_{\text {it-1 }}+\varepsilon_{D A}
\end{aligned}
$$




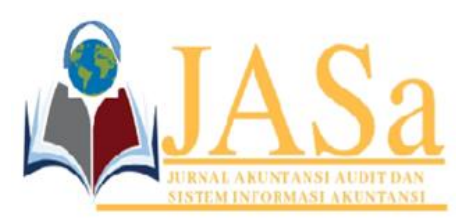

JASa (Jurnal Akuntansi, Audit dan Sistem Informasi Akuntansi)

Vol. 5 No.1/ April 2021

ISSN 2550-0732 print / ISSN 2655-8319 online

DOI; $10.36555 / j a s a / v 5 i 1.1514$

Description:

$\mathrm{TAC}_{\text {it }} \quad:$ Total accruals are calculated as net income less operating cash flows

$\mathrm{A}_{\mathrm{it}-1} \quad:$ Total assets of company $\mathrm{i}$ in year $\mathrm{t}-1$

$\triangle R E V_{\text {it }} \quad$ : Change in sales of company $i$ in year $t$

$\triangle R C_{i t} \quad$ :Change in receivables of company $i$ in year $t$

$\mathrm{PPE}_{\text {it }} \quad$ :The gross value of property, plant and equipment

$\mathrm{ROA}_{\mathrm{it}-1} \quad:$ ROA of company $i$ at the end of year $\mathrm{t}-1$

$\varepsilon_{\mathrm{DA}} \quad:$ Residual (discretionary accrual)

Testing the effect of abnormal audit fees with discretionary accruals is carried out by performing multiple linear regression analysis on the following model:

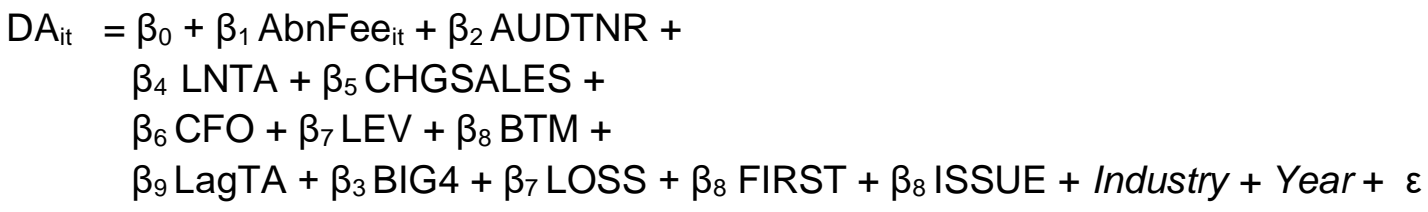

Description:

DA : Discretionary accrual

AbnFee : Abnormal audit fee is obtained from the residual value of the AFEE model equation

AUDTNR : Audit tenure, the length of service between KAP and clients

LNTA : Company Size, Natural logarithm of total assets

BIG4 : Company reputation, Dummy variable, 1 if the company is audited by Big4 and 0 if vice versa

CHGSALES : Company growth, sales volume divided by total assets

CFO : Operating cash flow, cash flow from operating activities divided by total assets

LEV : Leverage, total liabilities divided by total assets

LOSS : Loss, Dummy variable, 1 if the company reported a loss in the year and 0 if vice versa

BTM : Book to market ratio, the ratio of market value to book value of equity

LagTA : Total accruals for the past year are defined as earnings before extraordinary items less cash flows from operations measured by total assets

\section{Descriptive Statistics}

\section{RESULTS AND DISCUSSION}

The following table 1 presents the results of the statistical descriptions of the variables used in the main regression model.

The discretionary accrual (DA) variable has a minimum value of 0.0003

and a maximum value of 0.847 and an average of 0.59 and a standard deviation of 0.073 . Besides, it should also be underlined that of the sample companies in this study, 


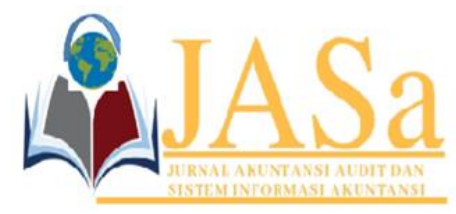

JASa (Jurnal Akuntansi, Audit dan Sistem Informasi Akuntansi)

Vol. 5 No.1/ April 2021

ISSN 2550-0732 print / ISSN 2655-8319 online

DOI;10.36555/jasa/v5i1.1514

176 or $42.5 \%$ of the companies that chose to be audited by the BIG4 public accounting firm and those who chose to be audited by non-BIG4 public accounting firms were 238 or $57.5 \%$.

These results indicate that in the audit market in Indonesia, sample companies prefer non-BIG4 public accounting firms to audit their financial reports compared to BIG4 audit offices. But the difference is not that big. Meanwhile, those who reported losses (LOSS) in the financial reports were 98 observations or $23.7 \%$. The remaining $76.3 \%$ or 316 reported profits. Pos_AbnFee which shows the number of dummy frequencies 0 are observations that have negative abnormal audit fees totaling $205(49.1 \%)$ and observations that have abnormal positive audit fees totaling 209 (50.9\%). This shows that the sample of this study has almost the same distribution of observations between positive abnormal audit fees and negative abnormal audit fees,

Table 1 Descriptive Statistic

\begin{tabular}{|c|c|c|c|c|c|c|}
\hline & $\mathbf{N}$ & Minimum & \multicolumn{2}{|c|}{ Maximum } & Mean & Std. Deviation \\
\hline DA & 414 & 0.0003 & \multicolumn{2}{|c|}{0.847} & 0.059 & 0.073 \\
\hline AbnFee & 414 & -2.087 & \multicolumn{2}{|c|}{1.629} & 0.000 & 0.469 \\
\hline ADTNR & 414 & 1 & \multicolumn{2}{|c|}{11} & 4.610 & 2.527 \\
\hline LNTA & 414 & 25.212 & \multicolumn{2}{|c|}{32.573} & 28.552 & 1.454 \\
\hline CHGSALES & 414 & -1.448 & \multicolumn{2}{|c|}{5.738} & 0.124 & 0.506 \\
\hline CFO & 414 & -0.601 & \multicolumn{2}{|c|}{0.594} & 0.065 & 0.119 \\
\hline LEV & 414 & 0.028 & \multicolumn{2}{|c|}{2.728} & 0.461 & 0.246 \\
\hline BTM & 414 & -21.089 & \multicolumn{2}{|c|}{82.045} & 3.419 & 9.109 \\
\hline LagTA & 414 & -0.724 & 0.7 & & -0.016 & 0.101 \\
\hline \multirow[t]{3}{*}{ Dichotomy Variables } & \multirow{2}{*}{\multicolumn{5}{|c|}{ Total and Persentase }} & Total \\
\hline & & & & & & Observasi \\
\hline & & \multicolumn{2}{|l|}{0} & \multicolumn{2}{|c|}{1} & \\
\hline BIG4 & & 238 & $57.5 \%$ & 176 & $42.5 \%$ & 414 \\
\hline LOSS & & 316 & $76.3 \%$ & 98 & $23.7 \%$ & 414 \\
\hline Pos_AbnFee & & 205 & $49.1 \%$ & 209 & $50.9 \%$ & 414 \\
\hline
\end{tabular}

Source: data that has been processed by the author (2019)

\section{Results of the Main Analysis}

Hypothesis testing is carried out on the main multiple linear regression model consisting of the dependent variable discretionary accrual (DA) as a proxy for accrual earnings management.

First, estimating discretionary accrual regression models for the entire sample, namely 414 firm-years observations to see the relationship between abnormal audit fees and 


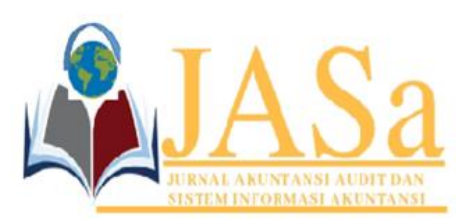

\section{JASa (Jurnal Akuntansi, Audit dan Sistem Informasi Akuntansi) \\ Vol. 5 No.1/ April 2021}

ISSN 2550-0732 print / ISSN 2655-8319 online

DOI; $10.36555 /$ jasa/v5i1.1514

audit quality without separating signs on abnormal audit costs, the results can be seen in the first column. Then the next column is the regression results on the sample by separating the abnormal audit fees based on the sign, namely positive abnormal audit fees and negative abnormal audit fees. Positive abnormal audit fees are the residual results of the audit fee model that are positive. Negative abnormal audit fees are the residual result of the audit fee model that is negative.

The following is a table that presents the results of multiple linear regressions to test the effect of abnormal audit fees on audit quality. Throughout this paper, the reported t-values are based on an adjusted basis, using a robust standard error corrected to overcome heteroscedasticity and firm-level clustering (Petersen, 2009).

Table 3 Results of Multiple Linear Regression Testing

\begin{tabular}{|c|c|c|c|c|c|c|}
\hline \multirow[t]{2}{*}{ Variable } & \multicolumn{2}{|c|}{$\begin{array}{c}\text { (1) } \\
\text { Entire sample }\end{array}$} & \multicolumn{2}{|c|}{$\begin{array}{c}\text { (2) } \\
\text { Positive Abnormal } \\
\text { Audit Fee }\end{array}$} & \multicolumn{2}{|c|}{$\begin{array}{c}\text { (3) } \\
\begin{array}{c}\text { Negative Abnormal } \\
\text { Audit Fee }\end{array}\end{array}$} \\
\hline & Coeff. & t-stat & Coeff. & t-stat & Coeff. & t-stat \\
\hline Constant & $0.1376^{* * *}$ & 3.28 & $0.1624^{* * *}$ & 3.11 & $0.1324^{* *}$ & 1.88 \\
\hline AbnFee & -0.0028 & -0.44 & $0.0305^{* *}$ & 2.28 & -0.0037 & -0.24 \\
\hline ADTNR & 0.0010 & 0.87 & -0.0002 & -0.16 & 0.0009 & 0.54 \\
\hline LNTA & $-0.0046^{\star * \star}$ & -3.15 & $-0.0054^{* \star \star}$ & -3.10 & $-0.0047^{\star \star}$ & -1.94 \\
\hline CHGSALES & 0.0075 & 1.31 & 0.0067 & 1.02 & 0.0177 & 0.77 \\
\hline CFO & -0.0873 & -1.33 & -0.0010 & -0.02 & -0.1389 & -1.56 \\
\hline LEV & $0.0895^{* * *}$ & 5.72 & $0.0318^{*}$ & 1.15 & $0.1171^{* * *}$ & 5.81 \\
\hline BTM & 0.0003 & 0.80 & 0.0004 & 0.78 & -0.0003 & -0.05 \\
\hline LagTA & $0.0778^{* *}$ & 1.94 & 0.0013 & 0.32 & $0.1455^{* *}$ & 2.26 \\
\hline BIG4 & 0.0096 & 1.38 & 0.0029 & 0.36 & 0.02138 & 2.03 \\
\hline LOSS & 0.0008 & 0.08 & 0.0144 & 1.55 & 0.0035 & 0.25 \\
\hline First & $0.0123^{* *}$ & 2.28 & $0.0112^{*}$ & 1.70 & 0.0123 & 1.54 \\
\hline Issue & 0.0012 & 0.15 & 0.0166 & 1.26 & -0.0021 & -0.20 \\
\hline $\mathrm{N}$ & \multicolumn{2}{|c|}{414} & \multicolumn{2}{|c|}{209} & \multicolumn{2}{|c|}{205} \\
\hline F-statistics & \multicolumn{2}{|c|}{3.87} & \multicolumn{2}{|c|}{2.37} & \multicolumn{2}{|c|}{3.50} \\
\hline Prob $>F$ & \multicolumn{2}{|c|}{0.0000} & \multicolumn{2}{|c|}{0.0016} & \multicolumn{2}{|c|}{0.0000} \\
\hline Adj.R2 & \multicolumn{2}{|c|}{0.3263} & \multicolumn{2}{|c|}{0.2090} & \multicolumn{2}{|c|}{0.3635} \\
\hline
\end{tabular}

Source: Stata output processed (2019)

Note: ${ }^{*},{ }^{* *},{ }^{* * *}$ signs are an indication of statistical significance at the $10 \%, 5 \%$ and $1 \%$ levels

From table 3, the first column is the regression result that examines the abnormal relationship between audit fees and discretionary accruals in the entire sample without 


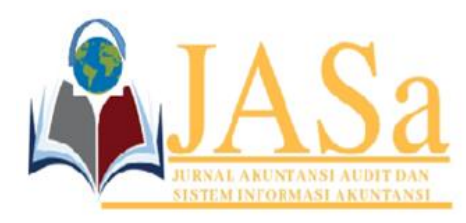

JASa (Jurnal Akuntansi, Audit dan Sistem Informasi Akuntansi)

Vol. 5 No.1/ April 2021

ISSN 2550-0732 print / ISSN 2655-8319 online

DOI; $10.36555 / j a s a / v 5 i 1.1514$

distinguishing positive and negative directions. The results of testing the relationship between abnormal audit fees and discretionary accruals (DA) showed a negative relationship with the abnormal audit fee coefficient value of -0.0028 but did not show a significant value. These results in accordance with hypothesis 1 which states that abnormal audit fees in the entire sample have no relationship with audit quality. This means that $\mathrm{H} 1$ is accepted. Each time the abnormal audit fee increases, the discretionary accrual will decrease by 0.0029 . This insignificant AbnFee coefficient is in line with the findings of Ashbaugh et al. (2003) and Choi et al., (2010), who also reported insignificant coefficients in their abnormal audit fee study, but these results are not in line with the findings of Jung et al. (2016). Research by (Jung et al. (2016) provides significant coefficient results on the abnormal relationship between audit fees and audit quality, an increase in discretionary accruals follows from an increase in abnormal audit fees.

According to research by Choi et al. (2010), the relationship between abnormal audit fees and audit quality is asymmetric, depending on signs of abnormal audit costs. If the relationship between discretionary accruals and abnormal audit fees is positive for the subsample with positive abnormal audit fees and insignificant for the subsample with negative abnormal audit fees, the results of this association analysis without reference to signs of abnormal audit fees are likely to lead to observations of insignificant results. This is because the two opposite effects can cancel each other out when two different subsamples are combined (Jung et al., 2016). The regression model for the entire sample has an $\mathrm{r} 2$ value of 0.3263 .

The second column presents the results of multiple regressions for samples with positive audit abnormal fees. The total sample of positive abnormal audit fees is 209 . When dividing the sample into positive abnormal costs and negative abnormal fees in columns 2 and 3 , it shows different results from column 1 . The coefficient for positive abnormal audit fees is 0.0305 with a significant value at a level of $5 \%$. This means that a positive abnormal audit fee has a positive and significant relationship with discretionary accruals. An increase in a positive abnormal audit fee will also increase discretionary accruals. Discretionary accruals and audit quality are inversely related. When the discretionary reports are high, it can be concluded that the audit quality is low. When discretionary accruals are reported low, the audit quality is concluded as high. These results indicate that hypothesis 2 , which estimates a positive relationship between abnormal audit fees and audit quality, is accepted. These results are also consistent with the research of Choi et al. (2010) and Jung et al., (2016).

The third column is the test results for samples with negative abnormal audit fees. The audit abnormal coefficient is 0.0037 and it is not statistically significant. The results showed that there was no relationship between negative abnormal audit fees and discretionary accruals. This result is consistent with previous research, namely Choi et al. (2010) and Jung et al. (2016). These findings indicate that abnormally high audit fees are negatively related to audit quality, in accordance with the economic bonding theory. However, no significant relationship between negative abnormal audit fees and audit quality was found, which could imply that auditors accept clients paying abnormally low fees only when audit risk is very low and audit quality is high with minimal audit effort assured. 


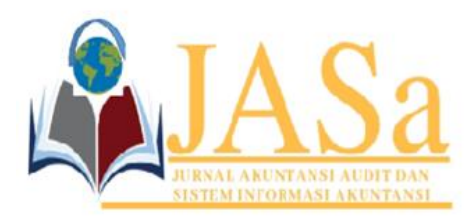

JASa (Jurnal Akuntansi, Audit dan Sistem Informasi Akuntansi)

Vol. 5 No.1/ April 2021

ISSN 2550-0732 print / ISSN 2655-8319 online

DOI; $10.36555 / j a s a / v 5 i 1.1514$

\section{CONCLUSION}

Testing the effect of abnormal audit fees on audit quality in manufacturing companies in Indonesia for the 2013-2018 period this research provides results that can be summarized in the following points: first, abnormal audit fees have no relationship with audit quality if tested on the entire sample without separating abnormal audit fees according to their positive and negative directions. Second, positive abnormal audit fees are positively related to discretionary accruals. A positive abnormal audit fee occurs when the audit fee received by the auditor exceeds the normal level of the audit fee. This means that abnormally high abnormal audit fees are negatively related to audit quality because increased discretionary accruals indicate decreased audit quality. This result is by the economic bonding theory. Third, a negative abnormal audit fee has no relationship with audit quality.

Suggestions that can be given from the results of this study are as follows: First, investors can become increasingly alert and aware that the disclosure of audit fees can be used as an indicator of how the external auditor's relationship with his client company. So that it can be used as consideration for economic decision-making. Second, further research can use other discretionary accrual calculations such as the model based on Ball \& Shivakumar (2006). Or by testing the relationship with real earning management (Alhadab, 2018).

\section{REFERENCES}

Alhadab, M. (2018). Abnormal audit fees and accrual and real earnings management: evidence from UK. Journal of Financial Reporting and Accounting, 16(3), 395-416.

Ashbaugh, H., LaFond, R., \& Mayhew, B. (2003). Do nonaudit services compromise auditor independence? Further evidence. The Accounting Review, 31(3), 1-22.

Asthana, S. C., \& Boone, J. (2012). Abnormal audit fee and audit quality. Auditing: A Journal of Practice \& Theory, 31(3), 1-22.

Ball, R., \& Shivakumar, L. (2006). The role of accruals in asymmetrically timely gain and loss recognition. Journal of Accounting Research, 44(2), 207-242.

Blankley, A. I., Hurtt, D. N., \& MacGregor, J. (2012). Abnormal audit fees and restatements. Auditing: A Journal of Practice \& Theory, 31(1), 79-96.

Choi, J. H., Kum, J. B., \& Zang, Y. (2010). Do abnormally high audit fees impair audit quality? Auditing: A. Journal of Practice \& Theory, 29(2), 115-140.

Eshleman, J. D., \& Guo, P. (2014). Do big 4 auditors provide higher audit quality after controlling for the endogenous choice of auditor? Auditing: A Journal of Practices and Theory, 33(4), 97-219.

Fitriany. (2016). Impact of Abnormal Audit Fee to Audit Quality: Indonesian Case Study. American Journal of Economics, 6(1), 72-78.

Frankel, R., Johnson, M., \& Nelson, K. (2002). The relation between auditors' fees for nonaudit services and earnings management. The Accounting Review, 77(s-1), 71114.

Hoitash, R., Markelevich, A., \& Barragato, C. (2007). Audit fees and audit quality. Managerial Auditing Journal, 22(8), 761-786. 


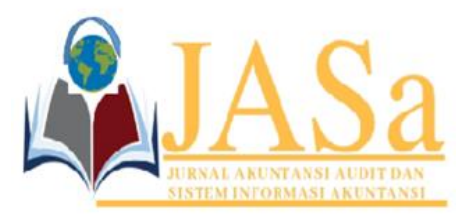

JASa (Jurnal Akuntansi, Audit dan Sistem Informasi Akuntansi)

Vol. 5 No.1/ April 2021

ISSN 2550-0732 print / ISSN 2655-8319 online

DOI; $10.36555 /$ jasa/v5i1.1514

Jeong, S. W., Park, J. I., \& Bae, S. H. (2014). The Associations among Auditor's Abnormal Audit Fees, Industry Expertise, and Discretionary Accruals. Korean Accounting Journal, 23(2), 143-190.

Jones, J. (1991). Earning Management during Impact Relief Investigation. Journal of Accounting Research, 29(2), 193-228.

Jung, S. J., Kim, B. J., \& Chung, J. R. (2016). The association between abnormal audit fees and audit quality after IFRS adoption: Evidence from Korea. International Journal of Accounting and Information Management, 24(3), 252-271.

Kalanjati, D. S., Nasution, D., Jonnergård, K., \& Sutedjo, S. (2019). Auditor rotations and audit quality: A perspective from cumulative number of audit partner and audit firm rotations. Asian Review of Accounting, 27(4), 639-660. https://doi.org/10.1108/ARA-10-2018-0182

Kinney, W. R., \& Libby, R. (2002). Discussion of the relation between auditors' fees for non- audit services and earnings management. The Accounting Review, 77(s-1), 107-114.

Kothari, S. P., Leone, A. J., \& Wasley, C. E. (2005). Performance matched discretionary accrual measures. Journal of Accounting and Economics, 39(1), 163-197.

KrauB, P., Pronobis, P., \& Zulch, H. (2015). Abnormal audit fees and audit quality: initial evidence from the German audit market. Journal of Business Economics, 85(1), 45-84.

Mitra, S., Deis, D., \& Hossain, M. (2009). The association between audit fees and reported earnings quality in pre- and post- Sarbanes-Oxley regimes. Review of Accounting and Finance, 8(3), 232-253.

Petersen, M. A. (2009). Estimating standard errors in finance panel data sets: Comparing approaches. Estimating Standard Errors in Finance Panel Data Sets: Comparing Approaches, 22(1), 435-480.

Xie, Z., Cai, C., \& Ye, J. (2010). Abnormal audit fees and audit opinion - further evidence from china's capital market. China Journal of Accounting Research, 3, 51-70.

Choi, A., (2016). Do auditors care about real earnings management in their audit fee decisions? Asia-Pacific Journal of Accounting \& Economics, 25(1-2), 21-41.

Cohen, D. A., \& Zarowin, P. (2010). Accrual-based and real earnings management activities around seasoned equity offerings. Journal of Accounting and Economics, $50(1), 2-19$.

Higgs, J. L., and Skantz, T. R. (2006). Audit and Nonaudit Fees and the Market's Reaction to Earnings Announcements. AUDITING: A Journal of Practice \& Theory, 25(1), 1-26.

Junaidi, dkk. (2014). The Effect of Audit Firm Tenure in Artificial Rotation on Audit Quality. Journal of Economics, Business, and Accountancy Ventura, 17(No. 3), 439448.

Kothari, S. P., Leone, A. J., and Wasley, C. E. (2005). Performance matched discretionary accrual measures. Journal of Accounting and Economics, 39(1), 163197.

Larcker, D. F., and Richardson, S. (2004). Fee Paid to Audit Firms, Accrual Choices, and Corporate Governance Journal of Accounting Research, 42(3), 625-658. 


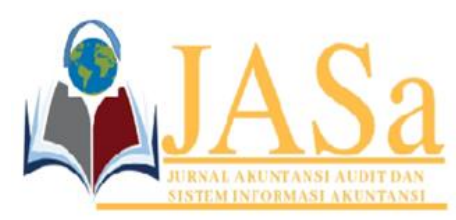

JASa (Jurnal Akuntansi, Audit dan Sistem Informasi Akuntansi)

Vol. 5 No.1/ April 2021

ISSN 2550-0732 print / ISSN 2655-8319 online

DOI;10.36555/jasa/v5i1.1514

Masri, I. (2018). Accounting Flexibility, Real Earnings Management, And Audit Quality: Evidence From Indonesia Listed Firms. International Journal of Business , Ecomonics, and Law, 15(5), 9-18.

Nkemjika, O. M., dkk. (2017). Audit Quality, Abnormal Audit Fee and Auditor Attributes International Journal of Management Excellence, 8(3), 973-984.

Oladipupo, A. O., dkk. (2016). Do Abnormal Audit Fees Matter in Nigerian Audit Market International Journal of Business and Finance Management Research, 4, 64-73.

Panda, B., dkk. (2017). Agency theory: Review of Theory and Evidence on Problems and Perspectives. Indian Journal of Corporate Governance, 10(1), 74-95.

Rusmanto, T., dkk. (2015). Factors Influencing Audit Fee in Indonesian Publicly Listed Companies Applying GCG. Procedia - Social and Behavioral Sciences, 172, 63-67.

Simunic, D. A. (1980). The Pricing of Audit Service: Theory and Evidene. Journal of Accounting Research, 18(1), 161-190.

Sinaga, E. A., (2018). Besaran Fee Audit Pada Perusahaan Yang Terdaftar Di Bursa Efek Indonesia. Media Riset Akuntansi, Auditing \& Informasi, 18(1), 19. 